\title{
特集 一般炭の利用
}

総

\section{高炉用コークスの製造に対する 非粘結炭の利用}

- 1977. 8. 12 受理一

住 金 化工 (株)* 桐谷 義男，露口 亨夫

住友金属工業(株)** 仁礼 尚道

\section{1. 緒言}

近年世界的な鉄鋼業の発展に伴って、コークス用原 料炭の需要は著しく増大し, その価格も年々上昇の一 途をたどっている。この傾向は一時的に緩和されるこ とがあっても，長期的にはますます重大な問題になる るのと思われる。

世界的な傾向として招そらく今後 $5 \sim 10$ 年の間に は，鉄鋼業界はその必要とするコークス用原料炭を十 分には入手できないような事態に追い込まれるのでは ないかと思われる。

わが国に沶いては持とらく今後10年ならずして，良 質原料炭の確保に相当の努力を払っても，な技流動性 の低下，イナート分の増加などの品質低下を余儀なく されまた価格高騰も驚くべきほどのものになると思 われる。

昨年，大阪で開催された第10回世界鉄鋼協会年次総 会に打いても，この問題はきわめて大きな関心をもっ て論じられ，特に1985年までの間にコークス用炭は， 世界全体で約1.6億 $\mathrm{t}$ の需要が増加する見込みであり， これに対処するためには，新規炭鉱の開発はもちろ ん, 非粘結炭の利用とコークス比の低減が急務である ことが強張された。

筆者らは成型コークス製造技術の開発と併行して, 従来既設のコークス炉に多量の非粘結炭を使用するこ とによって, 原料炭使用範囲の拡大とコークス価格の 低減を計ることを目的として，装入炭の事前処理法に 関する技術開発に多年の努力を重ねてきた。

その結果, D.K.S 方式成型コークスの製造につい ては, 高炉操業結果も含めて工業化の目途がつけられ

\footnotetext{
*和歌山市湊1850

**大阪市東区北浜 5 丁目 15
}

る段階にまで到達し，一方既設コークス炉を用いる方 法としては，新日本製鉄(株)で開発された成型炭配合 法と石油系粘結剤の利用技術とを基盤として幾多の工 夫を積み重ねて，非粘結炭を経済的に多配合できる新 しいシステムを完成させ，既に 2 年近い操業実績を得 るに至った。

本報では非粘結炭を高炉用コークス原料に活用する 技術の現状についてその概要を述べ，筆者らの関与し ている DKS 成型コークスならびにスミコール・シス テムによる非粘結炭多配合コークス製造技術開発の経 過とその操業を実績を紹介し各位の参考に供したい。

\section{2. 非粘結炭活用技術の現状}

製製鉄用コークスの原料に非粘結炭を活用する技術 あるいは使用し得る技術として，現在注目されている のは，(1)成型コークスの製造，(2)予熱炭装入， 成型炭配合，(4)粘結剤あるいは改質炭の製造に大別 される。本項では予熱炭装入法と粘結剤拉よび改質炭 について簡単に述べ，成型コークスと成型炭配合法に ついては次項以下で詳細に述べることにする。

\section{1 予熱炭装入法}

予熱炭装入は，1960年に Hagndange 工場で実用に 供された乾燥炭乾留技術1)と端を発して扣り，わ が国では石炭技術研究所から詳細な研究結果 ${ }^{2)}$ と共に 紹介された。

しかし当時の原料情勢, 大型コークス炉の発展や大 型実用設備に対する信頼性などの事情からその発展は 停滞していたが，コールテック社によるパイプ輸送法 ・ディディア社によるコンベア輸送法・サイモン社に よるラリーカー輸送法などの完成に伴い，近時にわか に注目をあび，世界各地で実用設備の建設が伝兄られ 操業結果もようやく一部公表される段階に至ってい 
$ろ^{3)}$ 。

現在は従来使用してきた配合炭を用い,コークス品 質を向上させる方向あるいは炬生産性を上げる方向が 主流と考兄られるが，効果発現のメカニズム ${ }^{4) 5}$ から 考えれば，非粘結炭を配合原料として一部使用できる ことは明らかである。

筆者らの実験結果6)によれば装入炭を予熱すること によって,コークスの冷間強度を損うことなく非粘結 炭を配合することは可能であるが，冷間に和ける品質 だけでなく熱間に物けるコークス性状も従来コークス と同等の品質が要求されるといら前提に立てば, 非粘 結炭の大量使用といら面からは後に求べるスミコール 法に一歩を譲るものと考兄られるが, 生産性やエネル ギーコストなどの面で有利な応用面を持って和り, 今 後さらに設備的に改良されて発展していくことが期待 される。

\section{2 粘結剂, 改質炭添加法}

コークス原料に粘結剤を使用する方法は, 鋳物用コ 一クスに石炭ピッチが古くから利用されていたことを 除けば，ごく最近に発展してきた技術である。

量的観点からみて, これらの原料は石油系重質油ま たは石炭抽出物に限定されるが, 基本的発想は, 従来 のコークス化現象に関する理解にそのまま受け入れら れるものであって, 今後その経済性と原料炭性状の推 移とによって発展の方向, 速度などが左右されるもの と思われる。

現状では境界がはっきりした分け方ではないけれど も，いわゆる人工粘結炭というべき性状を持つ方向7 と, 粘結剂として劣質炭と併用する方向 ${ }^{8}$ とがあり, 実用段階に入っているのは後者であるが，人工粘結炭 もすでに実験段階は終わって拉り，尾崎9らによれ ば，従来の石炭化度一流動性の関連範囲をはずれた特 異な性状を示す人工炭が得られ，コークス原料として も有用であることが示されている。

人工粘結炭の原料として現時点で注目されているの は，石油系重質油でその用途開拓のポテンシャルが大 きいことも西って，コークス用原料としての適性を得 るための処理法として触媒を使う方法などをはじめ, 枚挙にいとまのない汪どの多数の提案がなされて括り 今後の情勢次第で急速に実用化が進むものと思われる が, 一般的に硫黄含有量の高いことが, 将来とも問題 として残るのではないかと考觉られる。またこれらの るのの構造論的研究も盛んであるが, 現在のところコ 一クス化性の良否と直接関連を持つ指数は見あたらな いようである。

\section{3. 成型コークス}

成型コークス法は非粘結炭を大量に使用できる技術 として，長年世界各国で研究開発されて和り，そのう ち $\mathrm{BF}$ 法・FMC 法・DKS 法などは工業的規模で の高炉操業試験結果す発表されている。これらのプロ セスに関する論評・評価については既に多くの論説 ${ }^{10)}$ があるので省略し, 成型コークスの品位について触れ るとともに筆著らが関与した DKS 法の開発につい て述べる。

\section{1 成型コークスの品質}

成型コークスは本質的に軟化熔融性の小さい原料を 使用する必要があり, 通常 $70 \%$ 前後の非粘結炭が配 合されるところから収縮に基因する亀裂発生の程度と 粒子同志の融着の程度が従来コークスの製造にくらべ てはるかに強くコークス強度に影響する。このことは 強度をあるレベルに想定した時, 乾留条件と原料性状 に幅のせまい対応関係があることを示するので, 乾留 の条件によって著しく品位が変動する。

その一例として, 図 1 を示すが乾留条件は主に冷間 強度を支配して和り, 熔融性は主に熱間の強度に影響 する。

井田ら ${ }^{11}$ 西田ら ${ }^{12}$ は, 各種のプロセスで作られた成 型コークスの品質を検討し, 熔融型と接触型の構造に 大別し，成型コークスに执いては熱間の性状を重視す べさであると結論している。

管沢ら $\left.{ }^{13}\right)$ は, 図 2 亿示すように高炉模型実験結果か ら, 高炉内ガス流通状態に関連の深いレースウエイ付

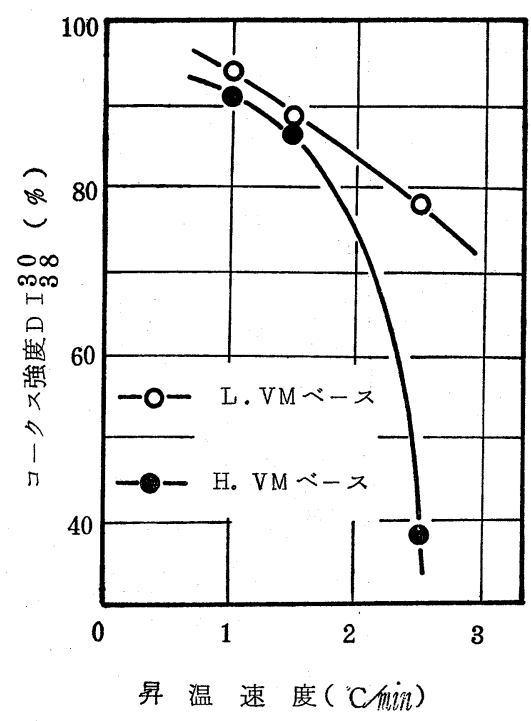

図 1 昇温速度の影響 


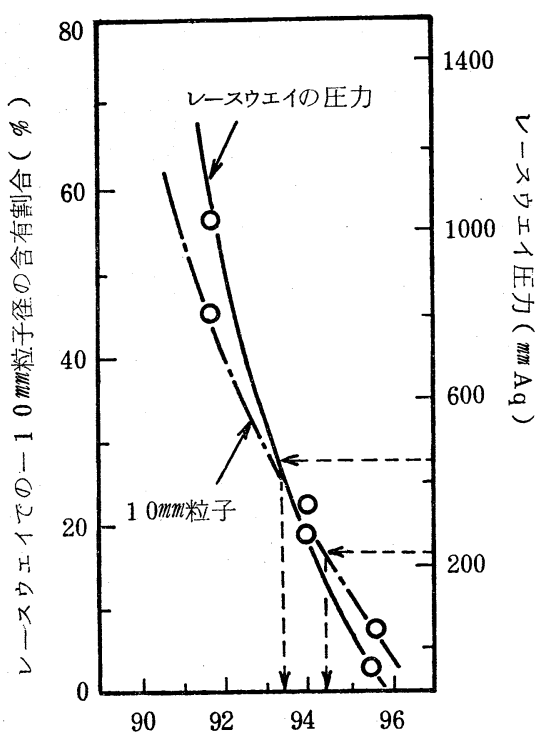

装入前の成型コークスの強度 DI 30 (\%)

図 2 高炉下部模型実験による成型コークス 強度の影響

近のコークス粒度分布を測定し, 総括的に成型コーク スの冷間強度は通常コークスに比較して若干高くする 必要があるとしてい。

また Tyutyunnikov ら ${ }^{14)} は$, 成型コークスには特
に微細孔隙構造が発達して扣り従来コークスと著しく 異なっていることを示している。

以上のごとく種々の性状の成型コークスがあり，か つその性状からみて，もともと従来コークスとはかな り異なるものであると考えるべきで，コークスの見挂 密度あるいは喜密度が異なる影響を別として成型コ一 クスの性状が従来コークスの性状に類似すればよいと いらだけでは, 成型コークス実用化の可能性は相当に 限定されざるを得ない。

成型コークスが高炉に拉いて真に必要な諸特性は, いかなる水準にあるか，という基本的な命題が解決さ れぬ限り，高炉テストを通じてトライアンドェラーに よる総括的な評価の積み重ねが必要であり，このこと が成型コークスの発展普及に一つの大きな障害になっ ていることは否定できない。

\section{2 .1 大型傾斜炉の開発}

1975年 4 月，西独 Didier 社，京阪煉炭，住友金 属, 住友商事の共同研究の結果開発された，D.K.S システムによる大型試験炉の試験操業が開始された。

本炉は炉容 $29.9 \mathrm{~m}^{3}$, 炉幅 $450 \mathrm{~mm}$, 炉高 9,500 $3,700 \mathrm{~mm}$, 炉底傾斜 $30^{\circ}$ の外熱式成型コークス乾留 炬で，炭化室は 1 門であるが左右に抜熱用のダミー炭 化室が付設され，抜熱量をコントロールして隣接窯の 熱的な影響を加えることがでさるように考慮されて抹 り，生産設備と同等の操業を行ならことができる。
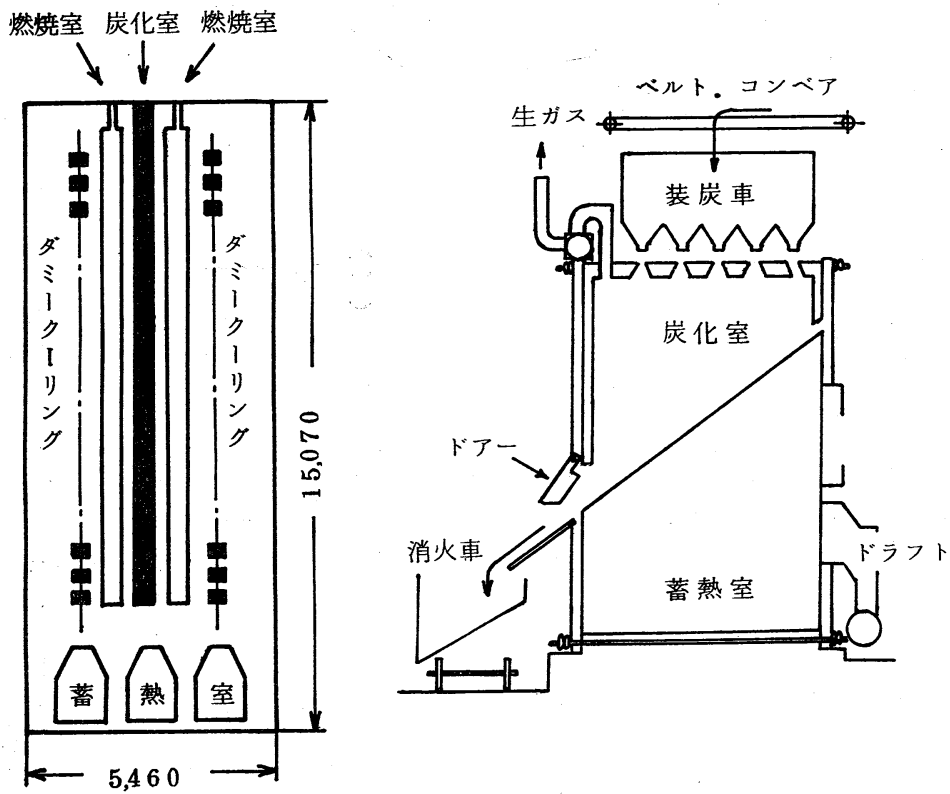

図 3 DKS デモ・プラント炉 
表 1 DKS 炉内のコークス強度の変動

\begin{tabular}{lcccccc}
\hline & $\mathrm{a}$ & $\mathrm{b}$ & $\mathrm{c}$ & $\mathrm{d}$ & $\mathrm{e}$ & $\mathrm{f}$ \\
\hline $\mathrm{DI}_{15}^{30}$ & 94.5 & 94.2 & 95.0 & 95.8 & 94.0 & 94.7 \\
$\mathrm{DI}_{15}^{150}$ & 85.8 & 85.5 & 86.7 & 88.7 & 86.0 & 86.5 \\
\hline
\end{tabular}

コークスサイドーマシソサイド

図 3 にその概要を示した。

本炬は，傾斜炉であるが，炭化室内の温度分布は良 好で，各部分ともほとんど同時に乾留を終了してい る。

また炉内各部のコークス強度バラッキは, 表 1 に示 すように炉内位置による差は通常炉に比較して小さ く, 乾留過程は十分均一に進行していると. 考えられ る。

また同一幅の通常炉（湿炭装入）に比較して，同 一炉温での乾留時間は若干短縮され，フリュー温度 $1,350^{\circ} \mathrm{C}$ で約 15 時間となり，成型炭が乾燥されている 場合には，脱水期と考えられる $100^{\circ} \mathrm{C}$ 付近での滞留時 間が短くなり，乾留時間は約 $20 \%$ 短縮されて 12 時間 前後となる。これは成型炭であるため, 乾留進行ゾー ンがそれぞれ独立して特り，炉内空間が多いことから 熱伝導が良好であることに起因するものと考兄られ る。

本炉からの排出は，炉底下部のドアを開くことによ る自然落下に依存することから, 乾留中の成型炭どら しの融着を防止する必要があり強度の 維持と相挨っ て，原料配合の適正化が運転操作上重要な要因になる が，この点については成型炭水分の減少を兼祆る予備
表 $2 \mathrm{DKS}$ 成型コークスとブリケットの品質

\begin{tabular}{|c|c|c|c|c|c|}
\hline \multicolumn{3}{|c|}{ 配 合 No. } & \multirow{2}{*}{$\frac{1}{22.4}$} & \multirow{2}{*}{$\frac{2}{23.0}$} & \multirow{2}{*}{$\begin{array}{c}3 \\
17.2\end{array}$} \\
\hline \multirow{6}{*}{$\begin{array}{l}\text { 成 } \\
\text { 型 } \\
\text { 炭 }\end{array}$} & (揮発分 & $(\%)$ & & & \\
\hline & 灰分 & $(\%)$ & 6.9 & 7.0 & 6.6 \\
\hline & 平均反射率 & & 1.44 & 1. 07 & 2.34 \\
\hline & 全活生成分量 & $(\%)$ & 30.3 & 30.4 & 20.9 \\
\hline & 酎圧強度 & $(\mathrm{kg} / \mathrm{p})$ & 310 & 370 & 356 \\
\hline & トトロンメル強度 & $\left(\operatorname{Tr}_{15}^{150}\right)$ & 95.5 & 94.3 & 95.8 \\
\hline \multirow{5}{*}{ コ } & 揮発分 & $(\%)$ & 0.9 & 0.8 & 0.6 \\
\hline & 灰分 & $(\%)$ & 9.0 & 9.4 & 8.5 \\
\hline & 全硫黄 & $(\%)$ & 0.49 & 0.51 & 0.54 \\
\hline & $\mathrm{DI}_{15}^{30}$ & $(\%)$ & 94.5 & 95.3 & 92.1 \\
\hline & $\mathrm{DI}_{15}^{150}$ & $(\%)$ & 84.8 & 86.8 & 74.6 \\
\hline ク & MS I & $(\%)$ & 61.7 & 64.4 & 55.4 \\
\hline \multirow[t]{3}{*}{ ス } & \multirow[b]{3}{*}{ 塊状反応性 } & $(\%)$ & 31.4 & 33.7 & 28.2 \\
\hline & & $(\%)$ & 12.7 & 10.9 & 18.8 \\
\hline & & $(\%)$ & 26.4 & 23.5 & 32.7 \\
\hline
\end{tabular}

処理を行ならことによって，許容原料配合範囲を拡大 することができる。使用原料の諸特性を吟味し, 必要 に応じて予備処理を行ならことにより広範囲の原炭の 使用が可能である。

以上のごとく本炉は，工業用設備として実用化可能 であることが，一年間にわたる試験操業によって立証 されたが，外熱式であることにより発生ガスの利用精 製に関しては，従来炉と同様に扱うことができるので 原料事情・国内情勢・立地条件などによって，成型コ ークスの優位性が認められる場合には, 成型コークス

表 3 高 炉操業結果

\begin{tabular}{|c|c|c|c|c|}
\hline & \multicolumn{2}{|c|}{ 小 倉 $\left(1,350 \mathrm{~m}^{3}\right)$} & \multicolumn{2}{|c|}{ 和歌山 $\left(1,633 \mathrm{~m}^{3}\right)$} \\
\hline & $\begin{array}{c}\text { 通常コークス } \\
100 \%\end{array}$ & $\begin{array}{c}\text { 成型コークス } \\
50 \%\end{array}$ & $\begin{array}{c}\text { 通常コークス } \\
100 \%\end{array}$ & $\begin{array}{c}\text { 成型コークス } \\
50 \%\end{array}$ \\
\hline 量 $(t / d)$ & 2,827 & 2,878 & 2,890 & 2,836 \\
\hline 量 $\left(\mathrm{Nm}^{3} / \mathrm{min}\right)$ & 2,300 & 2,300 & 2,350 & 2,315 \\
\hline 温 $\left({ }^{\circ} \mathrm{C}\right)$ & 1,146 & 1,150 & 1,100 & 1,100 \\
\hline 圧 $\left(\mathrm{kg} / \mathrm{cm}^{2}\right)$ & 1.93 & 2.07 & 1.30 & 1.44 \\
\hline 通 気 抵 抗 $(\Delta P / V)$ & 0.445 & 0.501 & 0.509 & 0.566 \\
\hline 焼 結 含 有 割 合 $(\%)$ & 92.8 & 93.7 & 56.0 & 58.0 \\
\hline ペレット含有割合 $(\%)$ & 0 & 0 & 20.0 & 20.0 \\
\hline$=-\eta$ ス 比 $(\mathrm{kg} / \mathrm{pig} \mathrm{t})$ & 437 & 424 & 458 & 474 \\
\hline オ $、 ル$ 比 $(\mathrm{kg} / \mathrm{pig} \mathrm{t})$ & 62 & 63 & 44 & 42 \\
\hline 燃 料 比 $(\mathrm{kg} / \mathrm{pig} \mathrm{t})$ & 499 & 487 & 502 & 516 \\
\hline 高炉ガス中のダスト (kg/pig t) & 8.7 & 8.8 & 14.2 & 23.9 \\
\hline スリップ 回 数 (回/d) & 0.5 & 0.5 & 0.4 & 1.4 \\
\hline
\end{tabular}


製造プロセスとして適用できる段階に達したといえ る。

\subsubsection{DKS 成型コークスの品質}

前記，大型傾斜炉を用いて乾留した各種サンプルか ら, 代表的配合例 3 種について成型炭拈よびュークス の性状を表 2 亿示した ${ }^{15)}$ 。

気孔率が小さいという成型コークスの特性を除けば 通常コークスの性状範囲に湾涪和さまっている。一般 的に成型コークスの難点といわれる $\mathrm{CO}_{2}$ との反応性 に関しても, 従来報告されているものに比較して優れ て扮り, 高炉操業に問題はなく, 顕微鏡による観察に よっても気孔は円型を呈し，よく融合し連続したコー クス壁が発達しているのが認められた。

開底式外熱コークス炉炕る DKS コークスと添 同一品質の成型コークスを用いた高炉操業試験の一例 を表 3 亿示すが，通常コークスに比較して全く遜色の ない操業結果が得られている。

高炉操業試験は未だ数少なく, Holgate らも指摘 しているようと使用石炭の適応性や高炉の大ささ，装 入物々関連した型や大きさの問題，さらに最適の高 炉操業法など検討すべき事項は多いが，このように DKS プロセスによって実用的な成型コークスの工業 的製造が可能であることが明確となったことは，今後 の成型コークス発展, 換言すれば製鉄用コークス原料 として大量の非粘炭を使用する技術の発展に対して大 きな意義をるつるのと思われる。

\section{4. 成型炭装入法の多様化}

バインダーを使用しないで成型炭を製造し，これを 全量コークス炉に装入する方法が，西ドイッの Volklingen に1959年建設されたカールスチールの $6 \mathrm{~m}$ 炉 で実施されている。わが国では1964年鉄鋼協会で国内 炭活用を目的として大規模試験が行なわれたが，設備 的にも若干の問題があり, 工業化されるには至らなか った。

これに対しバインダーを用いた成型炭を装入炭中に $30 \%$ 程度配合する方法は，旧八幅製鉄(株)で考案さ
れ，昭和46年戸畑で実施されたのを皮切りに，現在鉄 鋼各社の 8 事業所で採用され，成型炭製造能力は合わ せて 1 日 25 万t 以上飞達している。

この成型炭装入法の利点は, コークス強度がドラム $15 \mathrm{~mm}$ 指数で約 1.2 上昇することであるが，この強 度の上昇は非粘結炭配合も約 $20 \%$ 飞置き換えること ができる。すなわち本法は，コークス強度の改善また はコークス用炭の使用範囲の拡大を目的とした有力な 技術的手段として評価されている。

本法が開発された当初は，バインダーとして軟化点 $70^{\circ} \mathrm{C}$ 程度のタール中ピッチが使用されていたが(16) そ の後各社での実施の段階では軟ピッチまたはアスフ ルトなどが用いられ，住金化工(株)鹿島では，アスフ アルトを特殊な条件では熱処理して得られる特殊粘結 剤（以後 ASP と略記する）を使用している。をた和 歌山では, タールの簡易蒸留で常圧塔の塔底油として 得られるロードタールをバインダーとして使用してい る。

このように成型用バインダーが多様化するとともに 成型技術にも新しい発展が生じ, 成型炭配合システム は漸次多様化してきた。

\subsection{ASP を用いた改質ブリケット法}

筆者らは, アスファルトを $500 \sim 600^{\circ} \mathrm{C}$ で一時間程 度熱処理して得られるASPによって非粘結炭を改質 し, 低揮発分の米国強粘結炭に優るとも劣らない強粘 結炭が製造できることについて既に発表した ${ }^{17) 。 ま た ~}$ ASP を製造すためのアスファルトの熱分解プロセス については，昨秋大牟田に括ける第43回然料協会大会 に特いて詳細発表されている。表4 亿この ASP の性 状の一例を示す。

この ASP は $170 \sim 200^{\circ} \mathrm{C}$ の軟化点を有し, 芳香族 性に富む特殊な粘結剤で，このASP を非粘結炭に配 合すると図 4 亿示すように $\mathrm{DI}_{15}^{30} 90$ 以上の良質のコー クスが得られるが，中ピッチの場合にはこのような結 果は得られない。

このように ASP は単なるピッチの代替品ではなく

表 4 特殊 粘結剤 ASP の性状

\begin{tabular}{|c|c|c|c|c|c|c|c|c|}
\hline \multicolumn{3}{|c|}{ 工 業 } & 分 析 & $\bar{\pi}$ & 素 & 分 析 & \multicolumn{2}{|c|}{ 溶 剂 抽 出 } \\
\hline 軟 & 化 & 点 & $187{ }^{\circ} \mathrm{C}$ & 炭 & 素 & $85.9 \%$ & $n$-ヘプタン不溶分 & 79.0 \\
\hline 揮 & 発 & 分 & $41.4 \%$ & 水 & 素 & 5.8 & ベンゼン不溶分 & 50.4 \\
\hline & 定炭 & 素 & 58.4 & 窒 & 素 & 1.7 & キノリン不溶分 & 14.8 \\
\hline 灰 & & 分 & 0.15 & 酸 & 素 & - & & \\
\hline 硫 & & 黄 & 6.63 & 硫 & 黄 & 6.6 & & \\
\hline
\end{tabular}




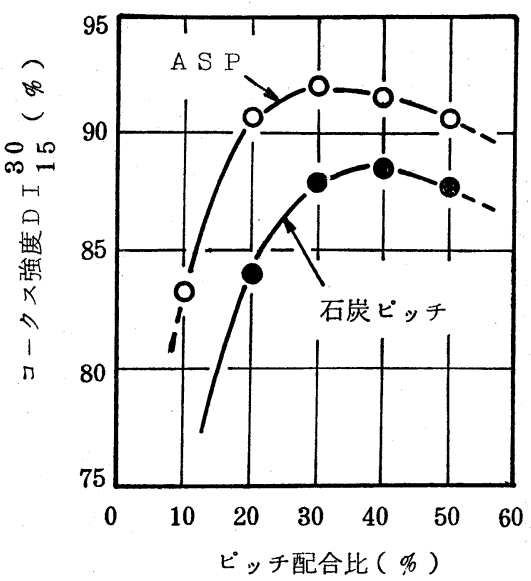

図 4 ピッチの配合効果

非粘結炭に対して独特の改質性を持つ一種の改質剂で ある。筆者らは ASP を成型炭配合システムにくみこ み，その改質効果と成型効果の相乗作用により非粘結 炭の多量配合が可能になるものと期待し，これを改質 ブリケット法と名付け，多くの実験を行なった。

ASP 30\% と非粘結炭 70\% とを単純に配合した缶 焼コークスは高炉用の通常装入炭とほぼ同等の強度を 持つ。また成型炭を $30 \%$ 配合する場合に，通常のバ インダー用いた成型炭中に $65 \%$ の非粘結炭を配合 し，全装入炭中に $20 \%$ の非粘結炭を使用してる， ほ 湆同等強度のコークスが得られる。しかし成型炭のバ インダーとして ASP を使用すれば，その改質効果に よってコークス強度はさらに改善され, 全装入炭中に $25 \%$ の非粘結炭を使用しても十分高炬に使用し得る コークス強度を確保できる実験例が得られている。

この改質効果は非粘結炭の性状銘柄によって大幅に 異なり，完全に不活性な無煙炭等に対しては，注とえ ぞ改質効果は期待できない。少なくとも $1 / 2$ 程度の CSN は必要である。

この ASPをバインダー兼改質剤として使用する改 質ブリケット法は，従来既設の成型炭設備を仕様変更 することなく，そのまま使用できるので，ASP のた めに特別の改質装置を必要としない。またバインダー として夏場の取り扱い困難な中ピッチを使用すること なく，石炭と全く同じ取り扱いのできる軟化点の高い ASP と自家生産のコールタールとを使用するだけで あるという利点がある。

鹿島では通常の成型炭配合設備が，昭和50年10月か ら稼動を開始したが，昨 51 年 3 月 ASP を年間 25 万t 生産し得るユリカ工業が操業を開始するに伴って，4
月から ASP をバインダーとする改質ブリケット法に よって非粘結炭の多配合コークスを製造し，鹿島製鉄 所の $5,050 \mathrm{~m}^{3}$ 高炉を含む大型高炉群に供給している。 4.2 低軟化点バインダーの利用

石炭の加圧成型には, 従来主として石炭系中ピッ チ，時には軟ピッチあるいはフスファルトなどがパイ ンダーとして使用され，バインダーの軟化点以上の温 度でバインダーと共に石炭を十分混練し，加圧成型し て得られた成型炭は，バインダーの軟化点以下の温度 まで泠却することによって，搬送貯蔵などの取り扱い 飞耐える成型炭強度を得ている。

通常の軟化点 $70 \sim 80^{\circ} \mathrm{C}$ の中ピッチを使用する場合 は, 石炭の加熱に相当量の蒸気を必要とし，また所定 の成型炭強度を得るためには，10〜15分程度の冷却が 必要であるなど広い設備面積と多額の設備投資が必要 である。また中ピッチは石炭ヤードにおいて，夏場軟 化固結するので近代化されたヤードで，大量のピッチ を機械的に取り扱うことは潘とんど不可能である。

低軟化点のバインダーを使用できれば，液体として の取り扱いがさらに容易となり，バインダー取り扱い を大幅に合理化することが可能となり，また混練温度 も低温となるので, 蒸気源, 冷却設備などが簡略化さ れ，成型コストが廉価になるのと共に，作業環境も大 幅改善される。しかし低軟化点バインダーでは，成 型炭の搬送貯蔵に耐えるだけの強度が得られないの で，コークス炉流入されるまでに破損しやすく，コ 一クス強度の低下を来たす招それがあるので，工業的 に実施することは困離であった。

筆者らは, タールの簡易蒸留に扔いて, 吸収油执よ びナフタリンを回収する際に常圧塔の塔低油として得 られる軟化点 $25 \sim 30^{\circ} \mathrm{C}$ のロードタールをバインダー として成型炭を製造し，コークス炉に装炭するまでの 成型炭の破損を，コークス品質に悪影響を与えない程 度にまで抑制することに成功したので，和歌山に每時 $150 \mathrm{t}$ の成型能力を持つ低温成型炭製造設備を設置し, 既に汇ぼ 2 か年の操業実績を得るに至った。またこの 低温成型システムに拈けるバインダーの特性と，混練 条件を適切に選定することによって, 成型原料を全く 加熱することなく，注とんど常温で成型することる可 能である。

\section{5. 非粘結炭配合コークスの性状}

\section{1 ユークス強度}

高炉用コークスの原料として若年炭を使用すると， 冷間強度が低下するだけでなく、コークスの反応性が

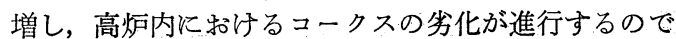




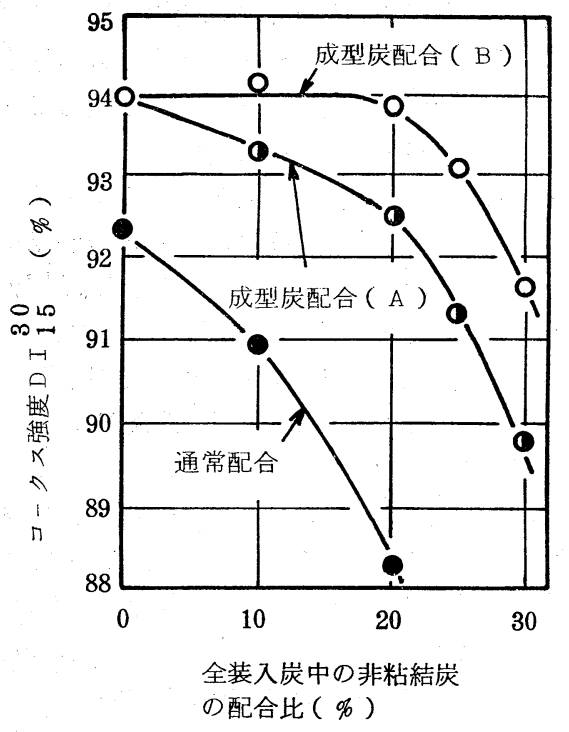

図 5 成型炭配合によるコークス強度の改善

高炉操業に悪影響を与える打それがあるとされてい る $^{18) 199}$ 。筆者らのシステムは非粘結炭を多量使用する ことを目指しており，使用する非粘結炭は資源的制約 によってほとんど地質年代の比較的新しい高揮発分非 粘結炭に限定されるので, ニークスの冷間強度ばかり でなく，反応性などの高温性状についても十分な検討 を行なってきだ20)。

通常の装入炭に非粘結炭を配合すれば，図 5 に示す ごとくその冷間強度は急速に低下し，ほとんど高炉の 使用に耐兄られないが，この非粘結炭配合装入炭の一 部 30\%を成型炭にすることにより, 冷間強度は大幅 に改善される。しかし曲線(B)に示すごとく, 非粘結 炭を成型炭中にの及集中配合することにより, 成型の 効果がすべての非粘結炭に及ぶので, 強度の改善はさ らに大きくなり, 同一強度を維持する場合は, 装入炭 中の非粘結炭配合比を $10 \%$ 程度高めることが可能で ある。

図 6 にコークスの高温性状の一つとして反応後強度 を示す。通常の装入炭に $10 \%$ 以上の非粘結炭を配合 したコークスは, 高温性状の面からも高炉の使用に不 安を与えるが, 成型炭配合法 (A)によって相当の非粘 結配合が可能となり，さらに非粘結炭を成型炭中にの 又集中配合することによって，曲線(B)に示すごとく 冷間強度の場合と同様に非粘結炭の 増配が可能とな る。

このように使用する非粘結炭の銘柄性状によっても 異なるが，非粘結炭を成型炭中に集中配合することに

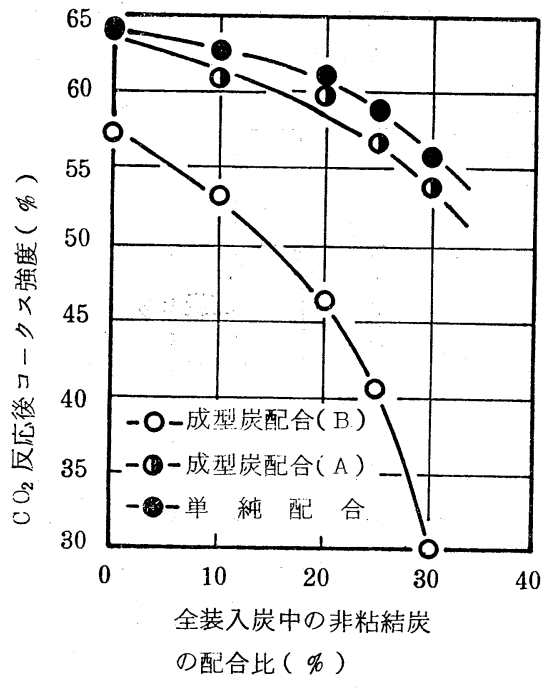

図 6 成型炭配合によるコークス品質の改善

より 20〜30\% の非粘結炭を使用して, 通常の高炉用 コークスとほぼ同等の冷間強度ならびに高温性状を有 するコークスを製造することができる。

ここでュークスの高温性状は, 広畑方式 ${ }^{21)}$ の塊状コ ークス小型反応性試験装置によるもので, $20 \pm 1 \mathrm{~mm}$ の塊コークス $200 \mathrm{~g}$ をレトルトに入れ，1,100息に 加熱し， $\mathrm{CO}_{2}$ を120分通して反応させ，その重量減少 率をもって反応量とし，この反応残渣を $120 \mathrm{~mm} \phi \times$ $700 \mathrm{~mm} l$ の鋼管に入れ, $20 \mathrm{rpm}$ で30分回転させ, 10 $\mathrm{mm}$ 節上 \%を反応後強度で表示したものである。

またバィンダーとして ASP を使用する改質ブリケ ット法を採用することによって，非粘結炭配合比をさ らに高めても高温性状の劣化しない高炉用コークスを 製造することができる。これは図 7 に示す通り非粘結 炭に ASP を添加することによって高温性状が改善さ れ, 非粘結炭と ASP との混合比 $7: 3$ 程度で, 通常 コークスとほぼ同等の高温性状を示すことからその改 質性を理解することがでさる。従って非粘結炭を成型 炭中に集中配合し，バィンダーとして ASP を使用す る改質ブリケット法に，さらに ASP の単純配合を併 用することによって，コークスの高温性状に悪影響を 与えることなく，30～35\% の非粘結炭を使用した高炉 用コークスを製造することも決して不可能ではない。

5.2 コークス組織

このように非粘結炭が成型あるいはASP 添加によ って, 冷間ならびに高温性状の改善される理由につい て2，3 の報告がある2223)。

筆者らは顕微鏡観察により, 非粘結炭から製造され 


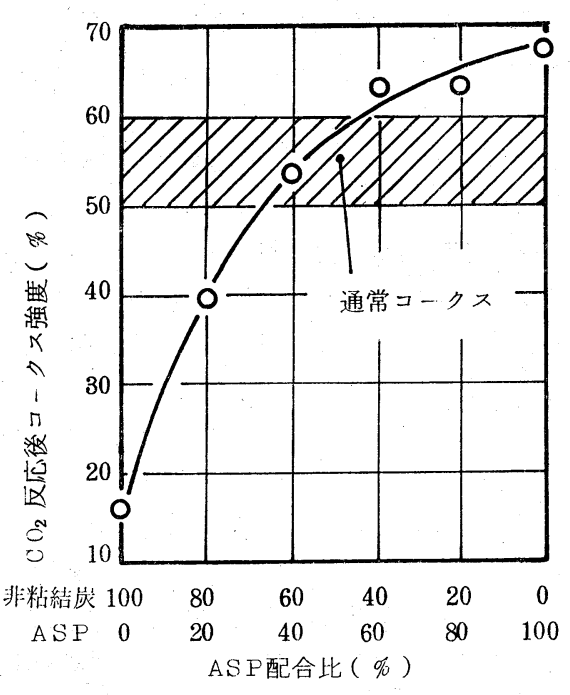

図 7 ASP 配合によるコークス品質の改善

るコークスにきわめて多く含有されている光学的等方 性組織が，加圧成型あるいは ASP 添加によって急激 そ減少し，異方性組織に転換していることを認めた。

ASP 添加㳊るる非粘結炭コークス組織変化を, 四 8 亿示す。コークス組織の分別定量は杉村らの方法 ${ }^{24}$ 飞従い, ポイントカウンター方式で行なっものであ る。非粘結炭の銘柄性状飞よっても異なるが, ASP $30 \%$ 程度の添加により, 非粘結炭の等方性組織は $1 / 2$ 程度異方化している。このような非粘結炭コークスの 異方性転化は，前述したように，非粘結炭の性状によ

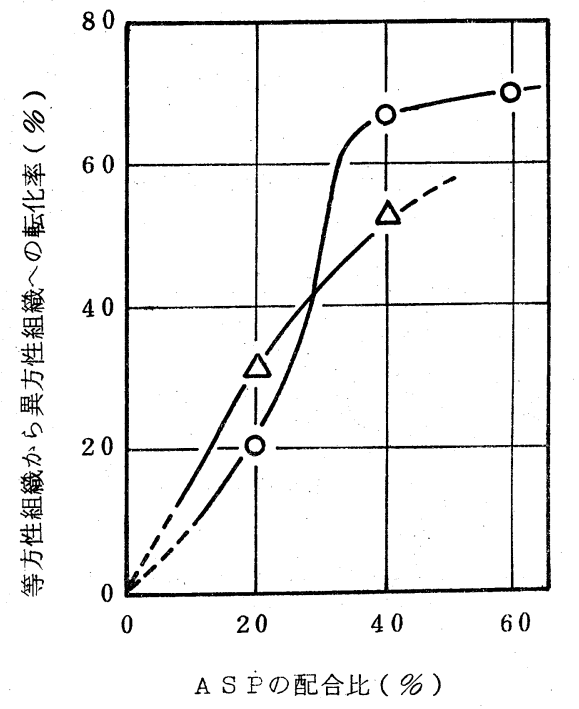

図 8 ASP 配合によるコークス組織の転化

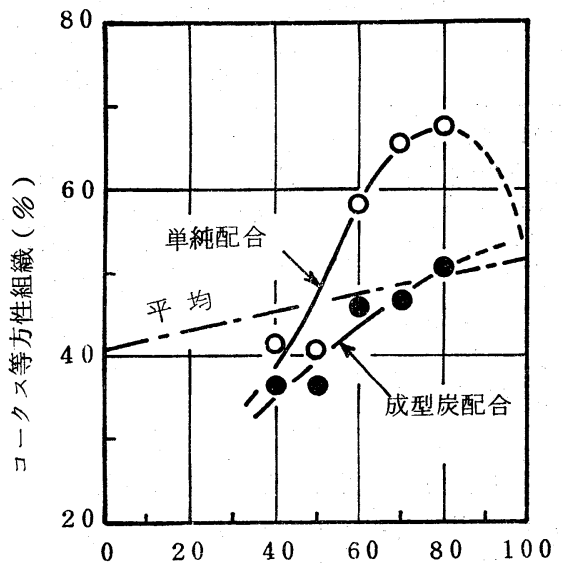

非粘結岸配合比 ( \%)

図 9 コークス等方性組織の挙動

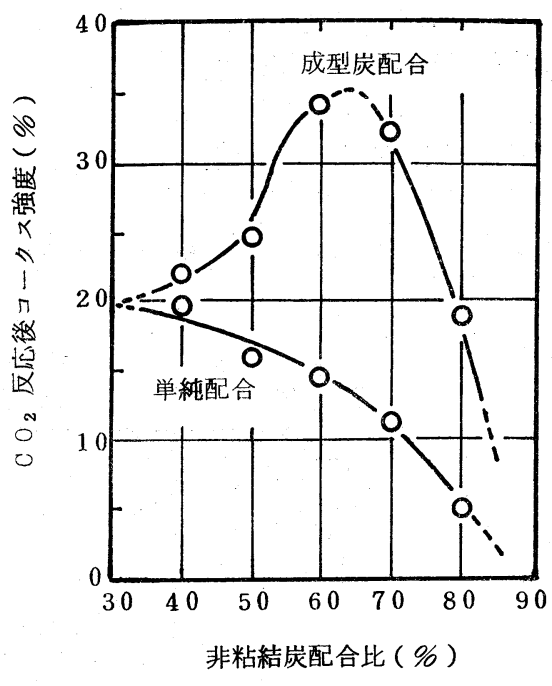

図 $10 \mathrm{CO}_{2}$ 反応後コークス強度に対する成 型効果

って大きく変わり, 例兄ば揮発分 $10 \%$ 以下 $\mathrm{CSN} ・ 0$ のような無煙炭では生起しないことが認められてい る。

成型炭を配合した場合も, 光学的に等方性の組織が 異方性組織に転換する現象が認められ，同時に熱間に 扣将 $\mathrm{CO}_{2}$ 反応量, 反応後強度に変化があらわれる。 これらの変化は, 成型炭原料の性質によって支配され ていると考兄られるが，その様相を典型的に示してい るモデル実験の結果を, 図 9,10 亿示した。

モデル実験は，表 5 亿示した性状を有する粘結炭と 非粘結炭の 2 種配合で行なったもので, 試料コークス 
表 5 サンブルの分析結果

\begin{tabular}{|c|c|c|c|}
\hline & & 粘 結 炭 & 非粘結炭 \\
\hline \multirow{3}{*}{$\begin{array}{l}\text { 石 } \\
\text { 炭 }\end{array}$} & (平均反射率 & 0.72 & 0.79 \\
\hline & 全活生成分量 & 95.0 & 61.2 \\
\hline & (最高流動度 & 4.78オーバー & 0.48 \\
\hline \multirow{4}{*}{$\begin{array}{l}z \\
1 \\
\eta \\
\text { ス }\end{array}$} & 等方性組織 & 40.9 & 518 \\
\hline & |モザイク組織 & 48.0 & 1.7 \\
\hline & そ の 他 & 4. 6 & 40.4 \\
\hline & （鉱 質 物 質 & 6.5 & 6.1 \\
\hline
\end{tabular}

は両炭の混合割合を変え，それぞれの $40 \%$ をタール 簡易蒸留塔底油（ロードタール）をバインダーとして 成型して配合，コークス化したものである。

コークスの組織分布, 特に等方性構造の量は, コー クス強度と密接な関連があり

$$
\begin{aligned}
\mathrm{DI}_{15}^{30}= & 93.36-0.350 \text { (等方性) } \\
& -0.141 \text { (微粒モザイク) } \\
\mathrm{SIR}_{s} *= & 40.84-0.34 \text { (等方性) } \\
& -33.56(\mathrm{Fe})+37.24(\mathrm{AD}) * * \quad \mathrm{r}: 0.828
\end{aligned}
$$

等方性構造の減少が，たとえば上式のように冷間強度 に関係があり ${ }^{25)}$ ま熱間強度に対しても大きな支配要 因である ${ }^{26)} こ$ こ，上記のごとくコークスの組織分
布量に好ましい変化をもたらす効果が，非粘結炭配合 のマイナス効果を打消す一因になっているものと考え れる。

\section{6. スミコールシステム実施の態様}

6.1 スミコールシステムの特徵

筆者らは石油系特殊粘結剂 ASP による非粘結炭改 質法の開発を進め，ASP を非粘結炭と組合わせて単 純に装入炭に配合することは，既に昭和46年頃から数 年来の実績を持っているが，さらは非粘結炭の改質を 成型炭配合法と組合わせることによって，高炉用コ一 クスの原料に $20 \%$ 以上の非粘結炭を使用し得る工業 的システムを開発し，既に 2 年程度の操業実績を得る に至った。また成型炭をより経済的に製造するために 新しいシステムを開発し, 逐次工業化を進めて扣り, これら一連のシステムをスミコールシステムと名付け た。その特徵とする所を要約すれば，次の 3 点になる。 6.1.1 特殊粘結剂 ASP による非粘結炭の改質 非粘結炭を ASP と $2 ： 1$ 程度の割合で単純に装入 炭中に配合することによって，強粘結炭と代替する ことができるが，さらに成型炭のバインダーとして ASP を使用する改質ブリヶット法を採用することに よって, 装入炭中に $20 \%$ 以上の非粘結炭を使用し,

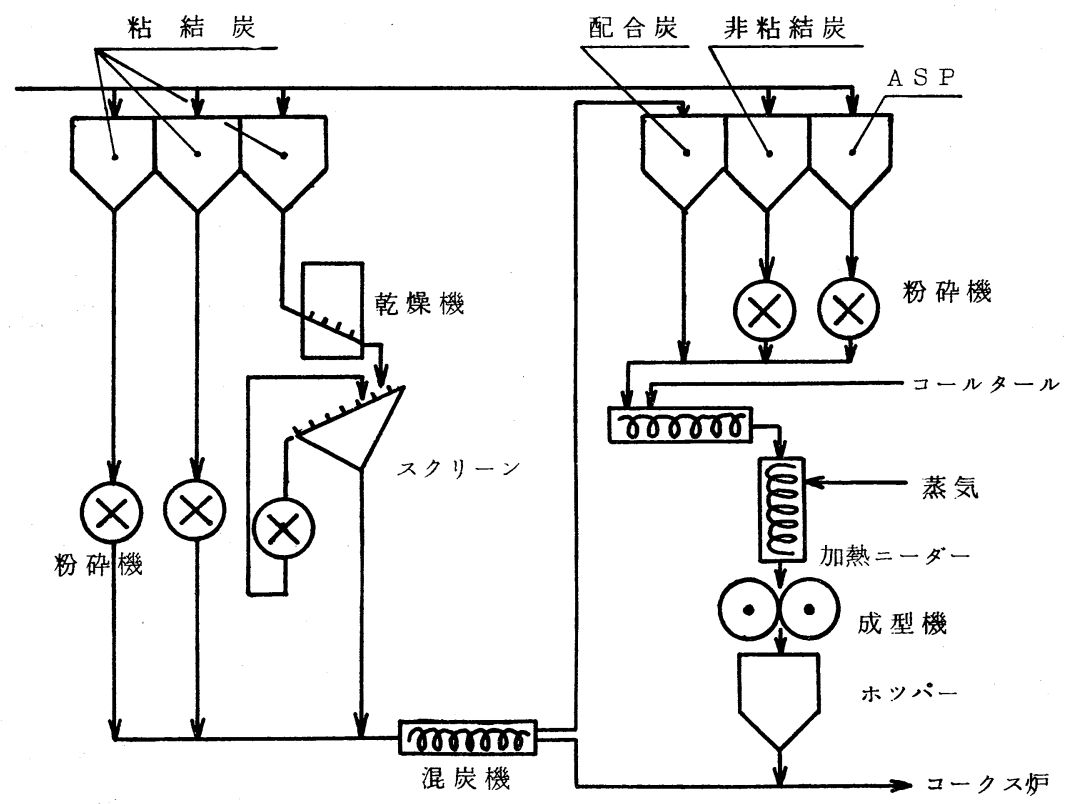

図 11 スミコールシステム, フローチャート（鹿島）

*引用文献 21）による $\mathrm{CO}_{2}$ との熱間反応後の強度指数を示す。

**ュークスの見掛密度 
大型高炉の使用に耐える良質のコークスを製造するこ とができる。

アスファルトを年間 100 万 $\mathrm{t}$ 処理する能力のある, ユリカ工業の ASP 動造設備は既に一年以上順調に稼 動し, 年間 25 万 $\mathrm{t}$ の ASP と 60 万 $\mathrm{t}$ の低硫黄燃料 油の生産を行なっている。

\section{1 .2 低軟化点バインダーの使用}

低軟化点バインダーを使用することによって，比較 的簡単な設備で成型炭を製造することができるが，さ らに混練方法を強化することによって, 比較的低温で 場合によってに，ほとんど常温できわめて経済的に成 型炭を製造することができる。

\section{1 .3 非粘結炭の集中配合}

非粘結炭を成型炭中に集中配合することによって, 装入炭中に $20 \sim 30 \%$ 非粘結炭を配合しても冷間強度 はもらろん, 高温性状の劣らない良質の高炉用ューク スを製造することができる。

\section{7. スミコールシステムの製造工程}

\section{1 改質ブリケット法}

鹿島では通常の加熱成型炭設備を用いて ASP によ る改質ブリヶットを製造し，既に一年以上の操業実績 がある。その基本工程を図11亿示す。

通常の配合設備で調整された装入炭の一部を分取し て，これに非粘結炭とASP を配合し，タールを添加 して加熱ニーダーで混練して成型するシステムで, こ れを改質ブリケット法と称している。

\section{2 低温成型法}

和歌山では特殊な粘結剤を用いることなく、タール 蒸留に括ける常圧塔の塔底油であるロードタールをバ インダーとして, 30〜 $35^{\circ} \mathrm{C}$ という比較的低い温度で, 非粘結炭集中配合の成型炭を製造し, ASP と非粘結 炭の単純配合とを併用して, 非粘結炭多配合コークス を製造し, 既に 2 年の操業実績があり, 昭和52年 2 月 以降, 非粘結炭 $25 \%$ 配合のコークスを高炉に供給し ている。これは低温成型であるために, 成型炭の耐压 強度が小さく, Soft Briquette 法とと称している。 その工程の基本型を図12亿示す。

これら和歌山・鹿島で実施しているスミコールシス テムは既設のコークス炉に扔いて, 石炭塔あるいは装 炭車にほとんぞ何等の改造を加觉ることなく順調な操 業を続けている。

\section{8. スミコールシステムの操業実績}

一昨 50 年 4 月和歌山で $150 \mathrm{t} / \mathrm{hr}$ の低温成型設備が, また 9 月には鹿島で $250 \mathrm{t} / \mathrm{hr}$ の加熱成型設備が稼動 を開始し、それぞれ ASP を使用しない単純な成型炭 一部配合方式として運転されてきたが，昨51年 3 月か ら ASP の使用を開始した。

和歌山と鹿島とでは混練温度が異なり, 和歌山の 35 ${ }^{\circ} \mathrm{C}$ 前後に対し, 鹿島では $95{ }^{\circ} \mathrm{C}$ 前後であるため, 設 備的にも和歌山はきわめて簡略化されている。

成型炭中に和敌非結炭の配合比は，和歌山では 40\% 程度から逐次配合比を高め $60 \%$ に達した。鹿島

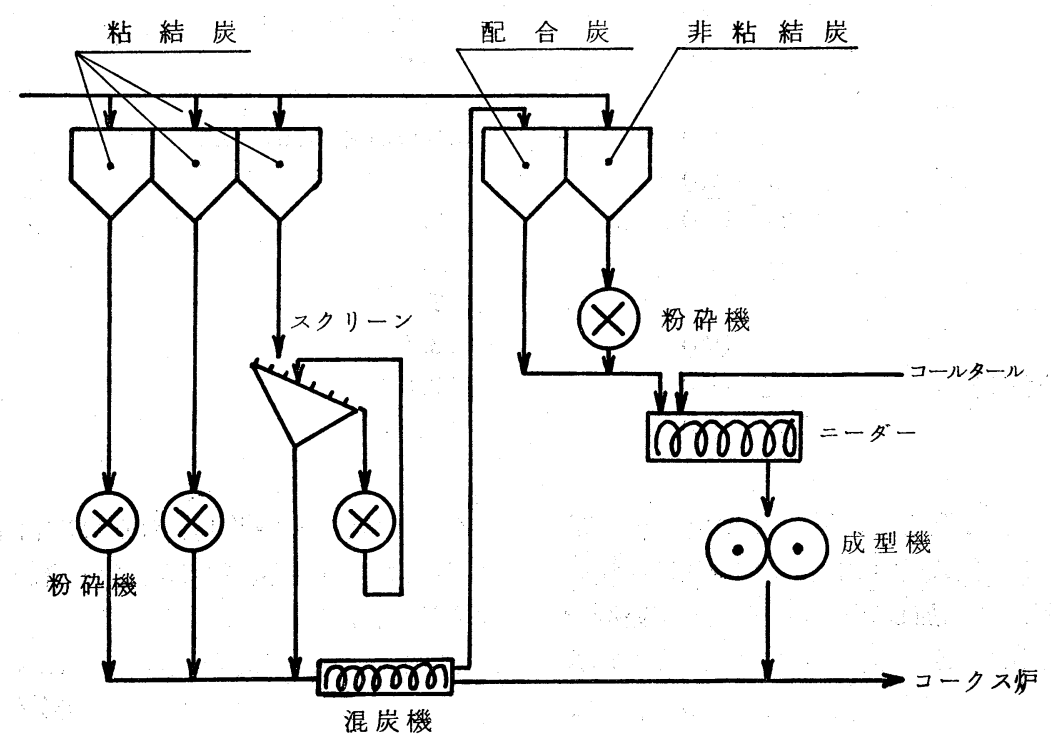

図 12 スミコールシステム, フローチャート（和歌山） 


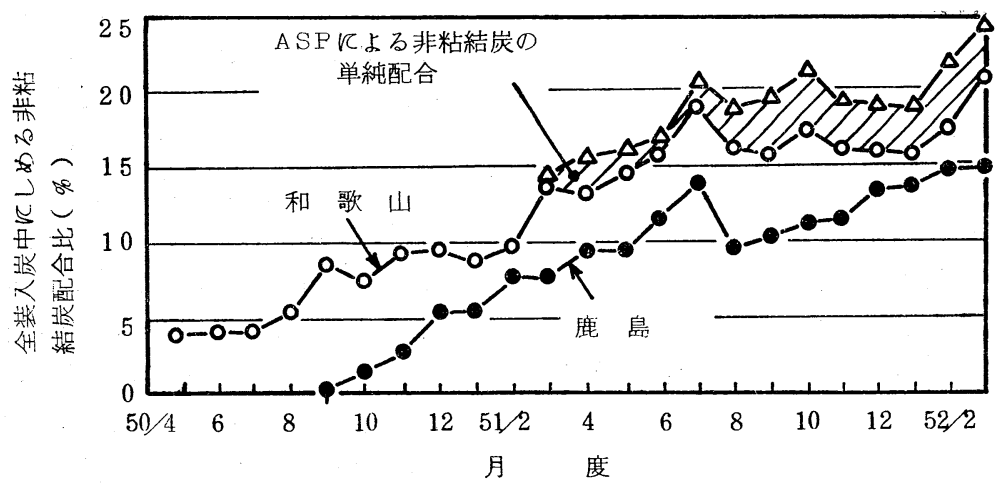

図 13 全装入炭中にしめる非粘結炭配合比推移

表 6 操 業 実 績 の 例

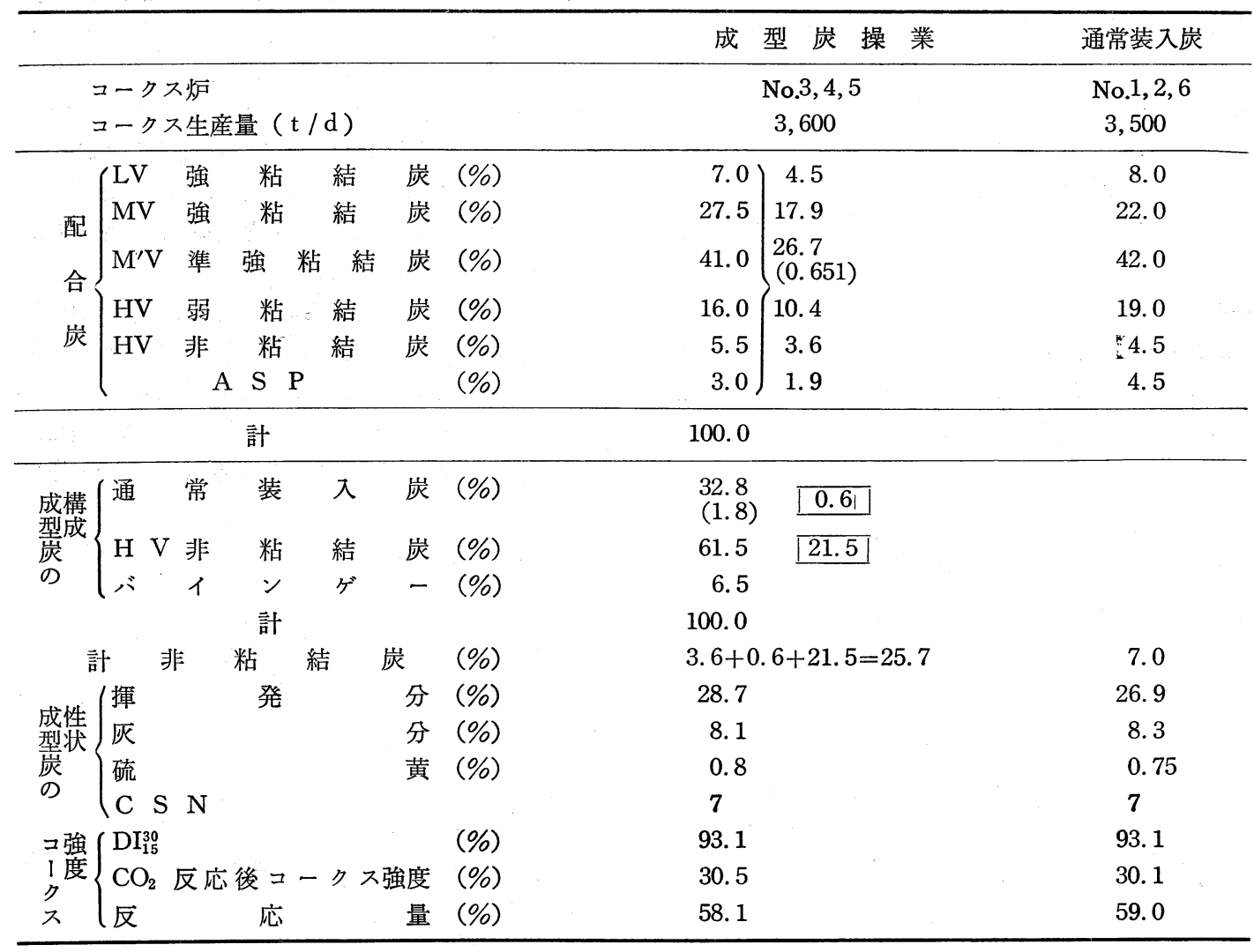

では $5,050 \mathrm{~m}^{3}$ の超大型高炉に供給するので慎重に非 粘比を高めている。装入炭中の成型炭配合比は何れる 10\% 程度から除々に増加し 30〜35\% に達している。

図13亿装入炭中に和ける非粘結炭の配合比推移を示 す。和歌山では ASP の単純配合によるるのを含めて 昨年 7 月から $20 \%$ を越光本年 3 月には成型炭のみで 20\% ASP 改質を含めて 25 26\% 飞達している。
このように和歌山・鹿島何れも約 2 年間にそれぞれほ ほ 60 万t 飞近い非粘結炭を使用し合わせて，120万 t にも達した。

和歌山では内容積 $2,170 \mathrm{~m}^{3}$ の No.3 高炉で非粘結 炭20 25\% 配合のコークスを 100\% 使用し, 鹿島で は 15 16\% 非粘結炭配合コークスを内容積 $5,050 \mathrm{~m}^{3}$ の超大型高炉で $100 \%$ 使用しいずれる長期間何等の問 
題を生ずることなく順調な操業が続いている。

和歌山で本年 2 月以降非粘結炭 $25 \%$ 配合を続けて いるが，この間の配合割合の一例を表 6 に示す。

No.3，4，5 ュークス炬は $5 \mathrm{~m}$ 炬で通常炭配合の中 にASP と組合わせて, 非粘結炭を使用し成型炭配合 法と組合わせている。No. 1 炉は, 炉高 $4 \mathrm{~m}$, No. 6 炉 は $6 \mathrm{~m}$ で, ASP 改質の非粘結炭のみ $5 \sim 6 \%$ 使用し ている。しかしコークスの品質は，この両系列で冷間 強度はもらろん高温性状も同等で高炉使用に際しても 全く区別をしていない。

\section{9. と め}

（1）非粘結炭を高炉用コークス原料として使用し得 る技術の現状を概観した。現在新しい生産技術として 確立し，かつ実績のあるのはスミコールシステムのみ であるが，今後各種の技術の発展に伴い，実績も拡大 していくものと期待される。

（2）D. K.S 成型コークスは，工業化可能段階に達 した。

（3）アスファルトを熱処理して得られる特殊粘結剤 を非粘結炭の改質剤として使用し, 成型炭配合法と組 合わせることによって, 相当多量の非粘結炭を配合し 得るシステムを工業化し, 既に一年以上の操業実績を 得た。

（4）一般に非粘結炭多配合コークスは高炉内の高温 域で劣化し, 高炉操業に悪影響を与えるものと危惧さ れていたが, スミコールシステムにおいては, 装入炭 中に $30 \%$ 程度の非粘結炭を配合しても冷間強度はも らろん, 高温性状の劣らないことが実験室的に確めら れ大型高炉の実操業でも非粘結炭 $25 \%$ 配合のコーク スが問題なく使用された。

\section{文献}

1) R. Loison, P.Foch, Revue de La Extrait de 1' Industrie Minerals, 43, 164 195 Feb(1960)

2) 石炭技術研究所報告 39 号
3) W. L. Mchenry, R. L. Lanp, A. W. Sellers (U. S. Steel Research), 私信など

4) J. W. Dowson, W. R. Gadsen, 387, Blast Furnace and Steel Plant, May (1966)

5) V. N. Dukhan and N. S. Gryazov, Coke \& Chemistry 12, 11 (1969)

6) 筆者ら未発表

7) 真田, 熊井, 木村, 川名 コークス特別会要旨，22（1970）

8）桐谷, 露口, 仁礼, 燃協誌, 51, 639 (1972)

9）尾崎, 山根, 然協誌, 55, 928 (1976)

10) J. I. F., 497 (1970), 313 (1972) Potter

11) 井田, 奥田, 山口, 然協誌, 51, 645 (1972)

12) 西田, 上村, 北村, ibid, 56, 29 (1977)

13）菅沢ら $8^{\prime}$ th regular meeting of the committee on technology, IISI (1976)

14) Yu. B. Tyutyunnikov, et al., coke \& chemistry, No.1, 18 (1971)

15）菅沢ら，燃協誌，51，668（1972）

16) コークスサーキュラー, 23, 22 (1974)

17）桐谷, 露口, 仁礼, 燃協誌, 51, 639 (1972)

18）八塚, コークスサーキュラー, 21, 17 (1972)

19) 山口, 奥原, 古井, コークスサーキュラー, 23, 261 (1974)

20）宮崎, 下田, 岩永, 桐谷, 花田, 鉄と鋼, 63, No.4, 983 (1977)

21）村上，原，石川，コークスサーキュラー, 23, 82 (1974)

22）佐々木，コークスサーキュラー，25，99 (1976)

23）奥原, 山口, 下川, 真田, コークスサーキュラ 一, 25, 312 (1976)

24）杉村, 熊谷, 木村, 本田, 然協誌, 48, 920(1969)

25）杉村, 熊谷, 木村, 燃協誌, 49, 744 (1970)

26）筆者ら未発表

\section{Utilization of Non-coking Coal for Production of Blast Furnace Coke}

by Yoshio Kiritani, Michio Tuyuguchi and Naomichi Nire* (Sumikin Coke Co., Ltd. *Sumitomo Metal Industries Co., Ltd.) 
expected to establsh the processes which could use non-coking coal for making of metallugical coke.

At first, four main technices which is anticipated to be available for this intention were described in outline. Secondary development of D.K.S formed coke process and SUMICOAL-system which consist of the use of special caking substance, ASP, and the method of briquette blend were elucidated, D.K.S process is not continious, but has reached to possible step could prduce formed coke in commercial.

SUMICOAL-system has consumed non-coking coal over one million ton age for the past year, and its coke quality was confirmed to even to conventional coke, through results of laboratory testes and $5,000 \mathrm{~m}^{3}$ class $\mathrm{B} . \mathrm{F}$ operation.

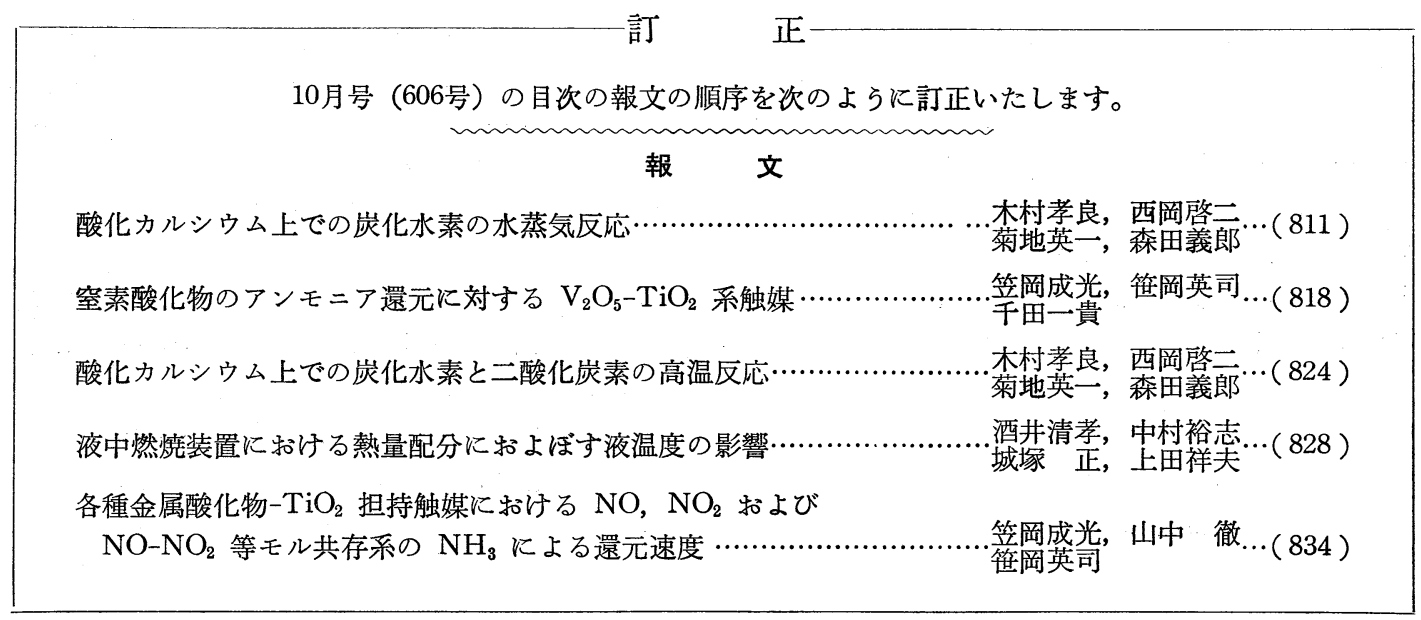

